\title{
PREVALENCE OF ORAL DISEASES AND THE ASSESSMENT OF THE SIMPLIFIED ORAL HYGIENE, DECAYED-MISSING-FILLING AND COMMUNITY PERIODONTAL INDICES AMONG INMATES OF THE RUSSIAN FEDERATION
}

\author{
PREVALÊECIA DE DOENÇAS BUCAIS E A INVESTIGAÇÃO DOS ÍNDICES DE \\ HIGIENE ORAL SIMPLIFICADO, DENTES CARIADOS-PERIDOS-RESTAURADOS \\ E ÍNDICE PERIODONTAL COMUNITÁRIO EM DETENTOS DA FEDERAÇÃO \\ RUSSA
}

\author{
Sergey Alekseevich KONDRATYEV ${ }^{\mathbf{1}}$; Anna Yu TURKINA ${ }^{\mathbf{1}}$; Ademir FRANCO ${ }^{\mathbf{1}}$; \\ Tatiana Vasilievna BUDINA $^{1}$; Alexey Genadievich OVSIENKO ${ }^{1}$ \\ 1. Department of Therapeutic Dentistry, Institute of Dentistry, Sechenov University, Moscow, Russia
}

\begin{abstract}
To investigate the prevalence of oral diseases and to assess the simplified oral hygiene (OHI-S) index, the decayed-missing-filled teeth (DMFT) index and the community periodontal index (CPI) among inmates incarcerated in the Russian Federation. The sample consisted of 175 male and 130 female inmates serving sentences at corrective colonies in the region of Kirov, Russia. Information about level of education, time of incarceration and general health status were collected via personal interviews. Additionally, the inmates underwent extra- and intraoral exams in the search for clinically detectable lesions and oral diseases. A quantitative analysis of the oral health was established through the assessment of OHI-S, DMFT and CPI indices. These indices were statistically tested for their association with inmates' time of incarceration and level of education. Complete dentition, partial tooth loss and edentulism were observed in 10.5\%, $81.9 \%$ and $7.5 \%$ of the sample. Dental caries (92.4\%), periodontal diseases (55.7\% periodontitis and $33.1 \%$ gingivitis), diseases of pulp and periapical tissue (87.9\%) were the most prevalent findings. The most prevalent disease in the oral mucosa was the cheilitis (64.9\%) followed by glossitis (21.9\%) and palatal nicotinic leukokeratosis (28.8\%). OHI-S and DMFT indices showed strong positive association with time of incarceration and level of education. Higher index scores were observed in inmates in prison for a longer time and with a lower level of education $(\mathrm{p}=0.001)$. These outcomes highlight the need for promoting oral health care policies to inmates incarcerated in prisons of the Russian Federation.
\end{abstract}

KEYWORDS: Diagnosis. Oral health. Prisoners. Public health.

\section{INTRODUCTION}

Dental health is directly related to quality of life (CÉSAR et al, 2016), while quality of life itself depends on several bio-psycho-social factors, such as the level of education, occupation, lifestyle (OSBORN, BUTLER, BARNARD, 2003), awareness of personal health care and motivation to enhance health status (NAIDOO, YENGOPAL, COHEN, 2005). Due to these factors, some populations remain with high rates of dental morbidity - even with the contemporary dental technology and knowledge available in practice. Recent studies in the Russian Federation showed that the oral health of the general population is directly related to socio-demographic status, behavioral factors and knowledge on oral health care (BLIZNIUK et al, 2014). Inmates figure a population potentially vulnerable to low socio- economic status, bad behavioral factors and poor knowledge on oral health care (REDDY et al, 2012). National statistic reports released in January $1^{\text {st }}$ revealed that nearly 602.176 inmates were incarcerated in prisons of the Russian Federation in 2018. This number indicates a rate of 450 inmates per 100.000 habitants.

While serving their sentences, the inmates may develop even worse and deficient health conditions that are associated not only with their stay in the penitentiary system, but also with unwillingness to have a healthy lifestyle and to comply with generally accepted oral hygiene standards. Screening and understanding the current scenario of oral health condition in Russian prisons is essential to drive major attention and design population-specific treatment strategies. However, the current scientific literature on Russian prisons and the (oral) health of their inmates is considerably 
scarce. Adopting the hypothesis that Russian inmates have a poor oral health condition, this study is justified to bridge a gap in the scientific literature and to support future health policies and strategies for the treatment of inmates in the penitentiary institutions of the Federal Penal Correction Service of the Russian Federation.

Based on the exposed, the present study aimed to evaluate social and demographic information of inmates of the Russian Federation, as well their general and oral health status.

\section{MATERIAL AND METHODS}

\section{Study design}

A cross-sectional and observational study was designed and performed after the approval of the ethics committee of Sechenov University, Moscow, Russia.

\section{Settings}

This study was carried between 2017 and 2018 in the men's Corrective Colony of strict regime \#11 in Kirovo-Chepetsk and in the women's Corrective Colony \#33 in Kotelnich, both in Kirov region, Russian Federation. Data were collected through in three phases: I) interviews via standard anamnesis and anamnesis forms, II) medical history search in inmates' files previously filled by medical professionals; and III) clinical examination. In the interviews, social and demographic data were collected - including the age, time of incarceration and educational level. Next, medical history search was conducted in the medical files of each inmate in order to retrieve information of their general health status - including eventual reports of previous or current systemic diseases. In the third phase, the clinical investigation of the oral health was performed in all inmates by trained and experienced professional. Specifically in this phase, the oral examinations were performed in two phases: III.I) intra and extraoral qualitative examination and III.II) intraoral quantitative examination. The first consisted of an observation for tooth count in the search for partial tooth loss or edentulism, and a following subjective search for oral diseases. In order to guide standard search for oral diseases, the International Classification of Diseases $10^{\text {th }}$ revision - Clinical Modification (ICD-10 CM) was used. The second phase of oral examination consisted of an objective analysis guided by three indices of oral health: the simplified oral hygiene (OHI-S) index, the decayed-missing-filled teeth (DMFT) index and the community periodontal index (CPI). The dental instruments and material used during the oral examinations included disposable wooden spatulas, mouth mirrors and properly sterilized periodontal probes.

\section{Participants}

The sample was composed by convenience and availability. All the male $(n=175)$ and female $(n=130)$ inmates willing to participate in the study were included. The inclusion criteria consisted of inmates incarcerated at the men's Corrective Colony of strict regime \#11 in Kirovo-Chepetsk and in the women's Corrective Colony \#33 in Kotelnich, both in Kirov region, Russian Federation. The exclusion criteria consisted of inmates not willing to participate in the study. No participant was excluded from the study. The final sample consisted of 305 inmates with mean age of $36( \pm 3)$ years for males and $33( \pm 5)$ for females.

\section{Statistical analysis}

The obtained data underwent descriptive statistical analysis through the observation of absolute and relative values for the prevalence of oral diseases and quantification of oral health indices. Next, Pearson's correlation coefficient and t-tests were performed between the social and demographic data of the inmates with their scores quantified in the oral health indices. Statistical Package for Social Sciences (SPSS) software, version 16 assisted with the data organization and analysis. The level of statistical significance was set at $5 \%$ with a confidence interval of $95 \%$.

\section{RESULTS}

The average period of stay in prison was 5.5 $( \pm 2)$ years. More specifically, 155 inmates (males $=80$, females $=75$ ) served less than 5 years of sentence in prison, while 150 (males $=95$, females $=55$ ) served more than 5 years.

Based on scholar education, $111(36.4 \%)$ inmates $($ males $=73,41.71 \%$; females $=38,29.23 \%$ ) reached the lower secondary level; $171(56.07 \%)$ reached the upper secondary education (males $=87$, $49.72 \%$; females $=84,64.62 \%)$; and $23(7.54 \%)$ reached the tertiary education (males $=15,8.58 \%$; females $=8,6.15 \%$ ).

The investigation performed on medical history revealed, as main outcomes, that $29(9.51 \%)$ inmates (males $=14,8 \%$; females $=15,11.54 \%$ ) had the Human Immunodeficiency Virus (HIV), while $32(10.49 \%)$ inmates (males=20, $11.43 \%$; females $=12,9.23 \%$ ) had history of Hepatitis C.

The oral exam showed that only $10.5 \%$ of the inmates presented all the teeth in the oral cavity, 
while $81.9 \%$ presented partial tooth loss and $7.5 \%$ presented edentulism. The qualitative search for oral diseases revealed a high prevalence of dental diseases among the inmates (Table 1).

Table 1. Absolute and relative values for the prevalence of oral diseases according to the International Classification of Diseases $10^{\text {th }}$ revision - Clinical Modification (ICD-10 CM)

\begin{tabular}{lcc}
\hline & \multicolumn{2}{c}{ Prevalence } \\
\cline { 2 - 4 } ICD-10 CM Codes & n & \% \\
\hline K02 Caries of tooth & 282 & 92.4 \\
K03.0 Excessive attrition of teeth & 172 & 56.4 \\
K03.6 Deposits [accretions] on teeth & 273 & 89.5 \\
K04 Diseases of pulp and periapical tissues & 268 & 87.9 \\
K05.1 Gingivitis & 101 & 33.1 \\
K05.3 Periodontitis & 170 & 55.7 \\
K06.0 Gingival recession & 82 & 26.9 \\
K13.0 Cheilitis & 198 & 64.9 \\
K13.1 Cheek and lip biting & 162 & 53.1 \\
K13.21 Leukoplakia of oral mucosa including tongue & 25 & 8.2 \\
K13.24 Leukokeratosis nicotina palati & 88 & 28.8 \\
K13.6 Irritative hyperplasia of oral mucosa & 21 & 6.8 \\
K14 Diseases of tongue & 67 & 21.9 \\
K08.1 Complete loss of teeth & 23 & 7.5 \\
K08.4 Partial loss of teeth & 250 & 81.9 \\
B37.0 Candidal stomatitis & 15 & 4.9 \\
\hline
\end{tabular}

n: absolute values; \%: relative values.

Diseases of the teeth and periodontal tissues were the most common, namely caries $(92.4 \%)$, pulp and periapical diseases $(87.9 \%)$, periodontitis $(55.7 \%)$ and gingivitis $(33.1 \%)$. In the oral mucosa, cheilitis $(64.9 \%)$ was the most prevalent disease (Fig. 1) followed by palatal nicotinic leukokeratosis $(28.8 \%)$ and glossitis $(21.9 \%)$.

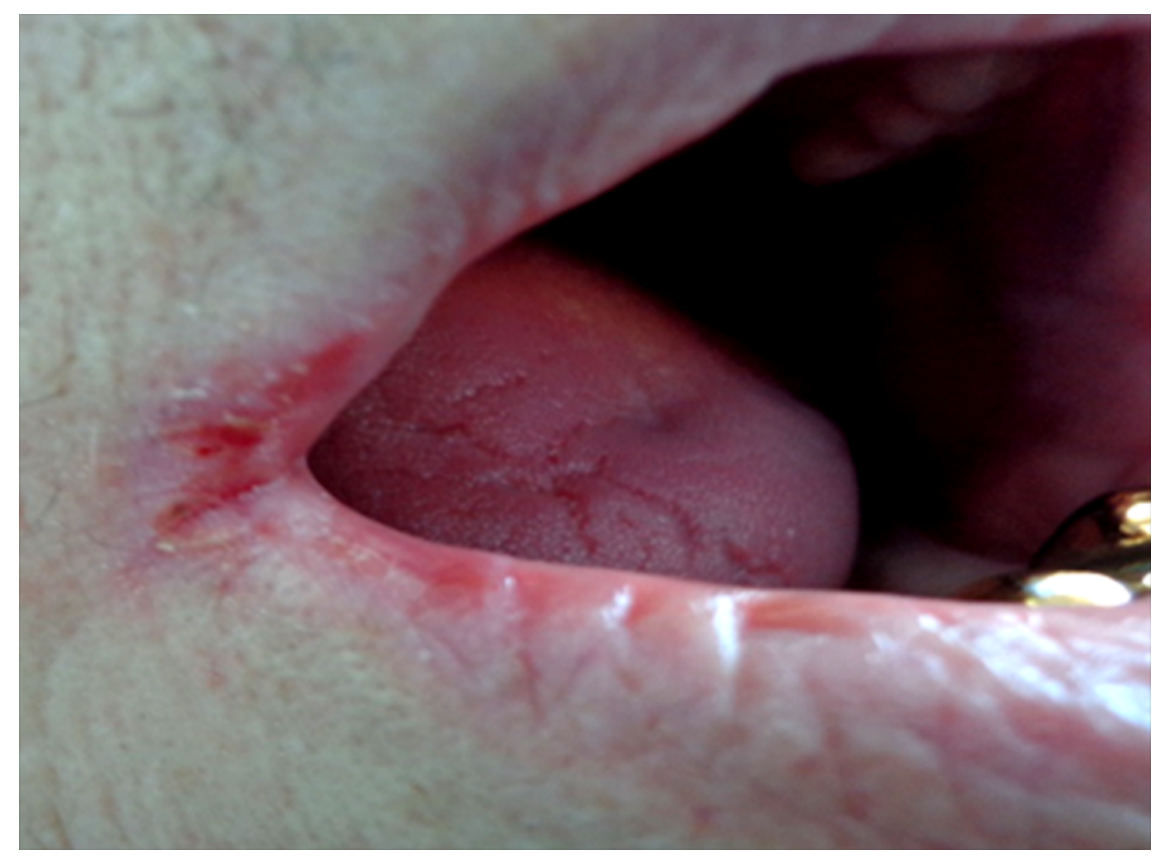

Figure 1. 33-year-old female inmate incarcerated for 3 years presenting angular cheilitis

The quantitative analysis of the oral cavity resulted in a mean OHI-S score of $2.42( \pm 0.03)$ for male inmates incarcerated for less than 5 years and a mean score of $3.11( \pm 0.03)$ for inmates in prison for more than 5 years. Among female inmates, the scores for incarceration periods higher or lower than 
5 years reached $2.53( \pm 0.03)$ and $2.62( \pm 0.03)$, respectively. The mean DMFT scores among all the examined inmates was $14.86( \pm 0.26)$. More specifically, the mean scores for decayed, missing and filled teeth were $6.48( \pm 2.18), 2.92( \pm 1.24)$ and $4.24( \pm 1.29)$, respectively. Table 2 shows the mean scores of OHI-S and DMFT indices calculated for four groups depending on sex and length of stay in the prison. In general, higher scores were observed in both indices in males and in inmates incarcerated for more than 5 years. Both in males and females and among inmates incarcerated for more or less than 5 years, decayed teeth were more predominant out of the DMFT index (Table 2).

Table 2. Mean scores of OHI-S and DMFT indices distributed based on the sex of the inmates and their time of incarceration

\begin{tabular}{|c|c|c|c|c|}
\hline \multirow{3}{*}{ Index } & \multicolumn{4}{|c|}{ Sex and time of incarceration } \\
\hline & \multicolumn{2}{|c|}{ Male } & \multicolumn{2}{|c|}{ Female } \\
\hline & $<5$ years & $>5$ years & $<5$ years & $>5$ years \\
\hline D & $6.88( \pm 0.15)$ & $7.5( \pm 0.13)$ & $5.41( \pm 0.10)$ & $6.14( \pm 0.09)$ \\
\hline $\mathbf{M}$ & $3.52( \pm 0.11)$ & $5.75( \pm 0.11)$ & $2.90( \pm 0.08)$ & $4.80( \pm 0.10)$ \\
\hline $\mathbf{F}$ & $3.73( \pm 0.08)$ & $2.33( \pm 0.10)$ & $3.10( \pm 0.13)$ & $2.50( \pm 0.12)$ \\
\hline DMFT & $14.13( \pm 0.17)$ & $15.58( \pm 0.34)$ & $11.41( \pm 0.23)$ & $13.44( \pm 0.31)$ \\
\hline OHI-S & $2.42( \pm 0.03)$ & $3.11( \pm 0.03)$ & $2.53( \pm 0.03)$ & $2.62( \pm 0.03)$ \\
\hline
\end{tabular}

OHI-S: simplified oral hygiene index; DMFT: decayed-missing-filled teeth index; D: decayed; M: missing; F: filled

Table 3 shows that the outcomes of statistical tests between the scores of oral health indices and the demographic data of the inmates resulted in a positive correlation with age and a negative correlation with sex, both with statistically significant association $(\mathrm{p}<0.001)$.

Table 3. Outcomes of the statistical correlations and association between the time of incarceration and the age and sex of the inmates and their scores in OHI-S and DMFT indices

\begin{tabular}{ccccccc}
\hline & \multicolumn{7}{c}{ Time of incarceration } \\
\cline { 2 - 7 } Index & Correlation coefficient & $\boldsymbol{p}$ & $\mathbf{n}$ & $\begin{array}{c}\text { Partial } \\
\text { correlation coefficient }\end{array}$ & $\boldsymbol{p}$ & $\mathbf{n}$ \\
\hline Age & 0.57 & 0.001 & 305 & & & \\
Sex & -0.17 & 0.001 & 305 & & 0.001 & 301 \\
D & 0.58 & 0.001 & 305 & 0.44 & 0.001 & 301 \\
F & 0.33 & 0.001 & 305 & 0.17 & 0.001 & 301 \\
M & 0.56 & 0.001 & 305 & 0.36 & 0.001 & 301 \\
DMFT & 0.66 & 0.001 & 305 & 0.48 & 0.05 & 301 \\
OHI-S & 0.19 & 0.001 & 305 & 0.11 &
\end{tabular}

OHI-S: simplified oral hygiene index; DMFT: decayed-missing-filled teeth index; D: decayed; M: missing; F: filled; n: sample size; *: coefficient correlation linked with age and sex; $p$ : statistical association with a significance level set in $5 \%$.

Positive correlations and statistically significant associations were also observed between the scores of OHI-S and DMFT indices and the time of incarceration $(\mathrm{p}<0.001)$ for males and females (Fig. 2). Both indices also expressed statistically significant outcomes when tested for association with inmate's level of scholar education. The lower were the score in OHI-S and DMFT indices when the higher was the level of education $(\mathrm{p}<0.001)$. In the lower secondary, upper secondary and tertiary levels of education the OHI-S scores reached 3.6 $( \pm 0.31), 2.7( \pm 0.16)$ and $1.6( \pm 0.22)$, while the DMFT scores reached $18.5( \pm 0.28), 16.5( \pm 0.34)$ and $9.5( \pm 0.31)$, respectively. 

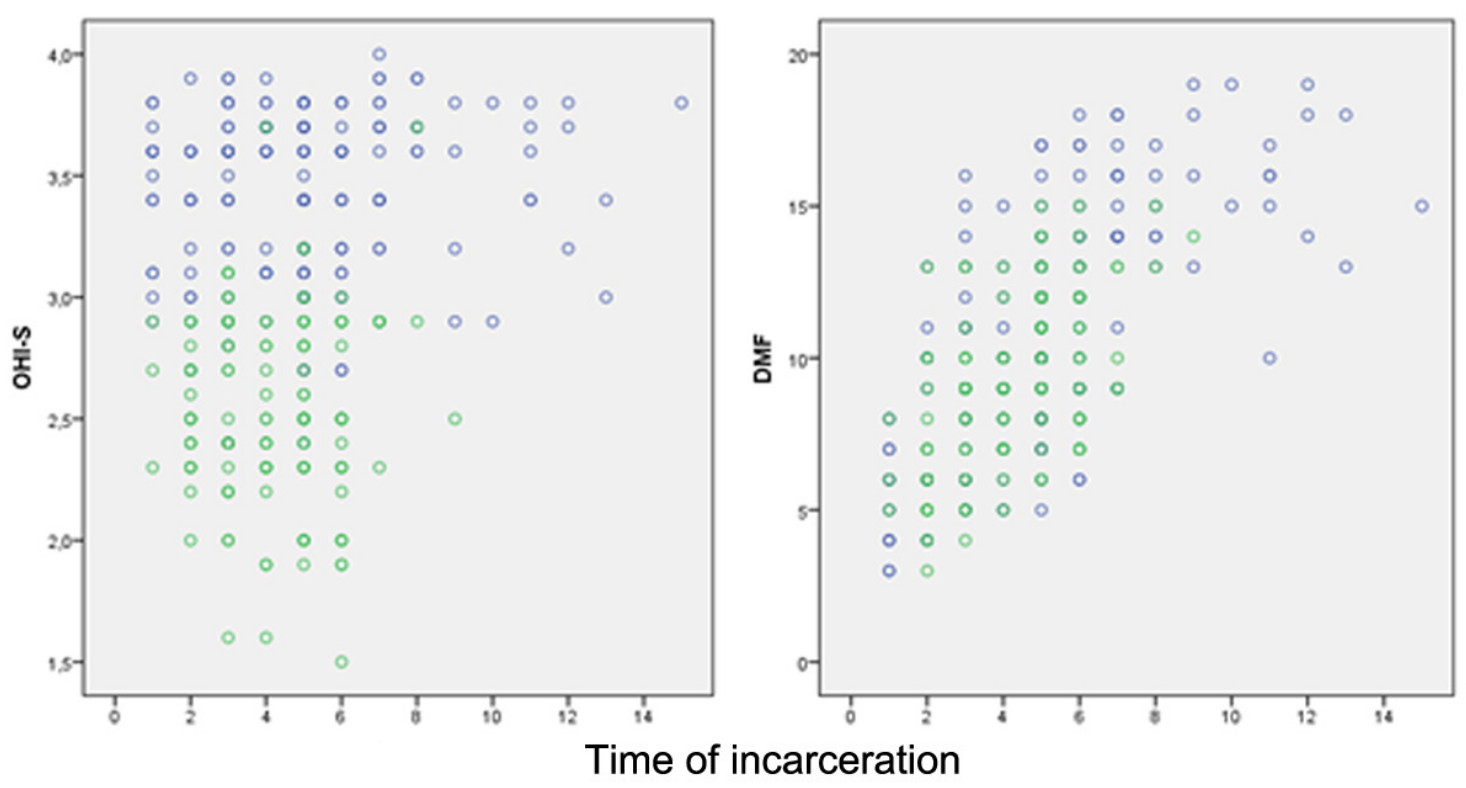

Figure 2. Distribution of male (blue) and female (green) inmates based on their scores in the simplified oral hygiene (OHI-S) and decayed-missing-filled teeth (DMFT) indices and time of incarceration (expressed in years)

In table 4, the CPI outcomes show that most of the males and females incarcerated less or more than 5 years reached the highest scores of 2 and 3 - compatible with the presence of calculus and shallow periodontal pockets, respectively.

Table 4. Distribution of inmates based time of incarceration, sex and highest score obtained in the CPI index

\begin{tabular}{|c|c|c|c|c|}
\hline \multirow{3}{*}{ Highest score } & \multicolumn{4}{|c|}{ Time of incarceration } \\
\hline & $<5$ years $(n=80)$ & $>5$ years $(=95)$ & $<5$ years $(n=75)$ & $>5$ years $(n=55)$ \\
\hline & \multicolumn{2}{|c|}{ Males } & \multicolumn{2}{|c|}{ Females } \\
\hline $\mathbf{0}$ & $0 \%(0)$ & $0 \%(0)$ & $0 \%(0)$ & $0 \%(0)$ \\
\hline 1 & $5 \%(0.37)$ & $0 \%(0)$ & $8 \%(0.55)$ & $1.8 \%(0.16)$ \\
\hline 2 & $36.3 \%(2.28)$ & $22.1 \%(1.47)$ & $46.7 \%(2.94)$ & $29.1 \%(1.9)$ \\
\hline 3 & $33.7 \%(2.13)$ & $33.7 \%(1.96)$ & $29.3 \%(1.44)$ & $32.7 \%(1.78)$ \\
\hline 4 & $20 \%(0.78)$ & $7 \%(2.11)$ & $12 \%(0.75)$ & $23.7 \%(1.31)$ \\
\hline $\mathbf{X}$ & $5 \%(0.44)$ & $9.5 \%(0.46)$ & $4 \%(0.32)$ & $12.7 \%(0.85)$ \\
\hline
\end{tabular}

CPI: community periodontal index; $\mathrm{n}$ : sample size; score 0: healthy periodontal condition; score 1: gingival bleeding; score 2: calculus; score 3: shallow pockets; score 4: deep pockets; x: less than two available. Outcomes in parenthesis show the mean number of sextants with highest scores between 0 and 4 .

\section{DISCUSSION}

The problem-based scenario regarding the dental status of inmates is relevant all over the world. Over the past 15 years, studies were carried to investigate the problems of penitentiary health care and, in particular, to assess the dental status of inmates. In India, the prevalence of caries among 800 prisoners was $97.5 \%$ (REDDY et al, 2012), while in South Africa, the mean DMFT score of persons in corrective institutions reached 15.45 (NAIDOO et al, 2005). This scenario is not only restricted to developing countries (LUNN et al, 2003). In England, a study conducted with female inmates showed a prevalence rate of $75 \%$ of carious cavities and a mean DMFT score of 12.3. Additionally, $66 \%$ of the female inmates had periodontal pockets deeper than $4 \mathrm{~mm}$ (HEIDARI et al, 2007). In Italy, a similar study performed with 500 inmates resulted in a mean DMFT score of 10.8, mean OHI-S score of 37.6, and a higher prevalence of CPI score 2 (NOBILE et al, 2007). Similarly to the previous scientific literature (WASH et al, 2008), the present study showed high levels of unsatisfactory oral hygiene (OHI-S index nearly 90\%), mean DMFT score of $14.86( \pm 0.26)$ and CPI scores $2(33.55 \%)$ and $3(32.35 \%)$ as the most prevalent.

The reason behind the poor oral hygiene observed in the sample of inmates may be justified 
based on several factors (WASH et al, 2008), such as the age and sex of inmates, culture, level of education, social status before incarceration and time of incarceration. The study conducted by Decerle et al. (DECERLE et al, 2012), 2012, illustrates this panorama. The authors showed that French inmates incarcerated for less than 2 years had DMFT scores significantly higher than those incarcerated for a longer period. With a similar approach, the present study showed the worse OHI$\mathrm{S}$ and DMFT and outcomes for the group incarcerated above 5 years in comparison to the group in prison for a shorter time. An additional and specific factor observed during the present study was the low level of knowledge and interest about oral hygiene and lack of motivation for dental treatment among inmates. In the Russian Federation, inmates receive new toothbrushes every 6 months and may have dental treatment in the colony. However, dental care is only searched when pain becomes intolerable. Inmates with symptomatic endodontic diseases usually search for dental treatment. However, they often manifest their willing for dental extraction instead of the multiplevisit endodontic treatment.

Knowledge and interest in oral hygiene may depend on scholar education (CARVALHO et al, 2006; ARMANI, CRUZ-SILVA, 2010). In the present study, inmates with tertiary education showed a mean DMFT score lower (9.5) than those with the lower secondary education (18.5). This outcome is corroborated with the predominance " $F$ " (filled teeth) scores in more educated inmates, which highlights their interest and search for dental treatment. Oppositely, in inmates with lower secondary education the "D" (decayed teeth) criterion prevailed. Differences between inmates with higher and lower levels of education were also confirmed with the analysis of the OHI-S index. These findings suggest that oral hygiene may be maintained or improved even after confinement. "M" (missing teeth) scores also varied between groups of inmates, but it deserves specific attention. In nearly $50 \%$ of the inmates, missing teeth were registered not because of dental extraction but as a result of fighting. Fractures of mandible and maxilla also emerge from prison conflicts. These findings point towards the need to understanding violence as health problem (SILVA, BENEDICTO, PARANHOS, 2013), especially because victims of violence need to be treated in a multidisciplinary environment that may include dental care. In the Russian Federation, inmates with severe injuries receive treatment in specialized clinics and afterwards return to incarceration. However, adequate rehabilitation of these inmates is a challenging task considering the potential infections and development of chronic inflammatory processes in the fracture zone (Fig. 3).

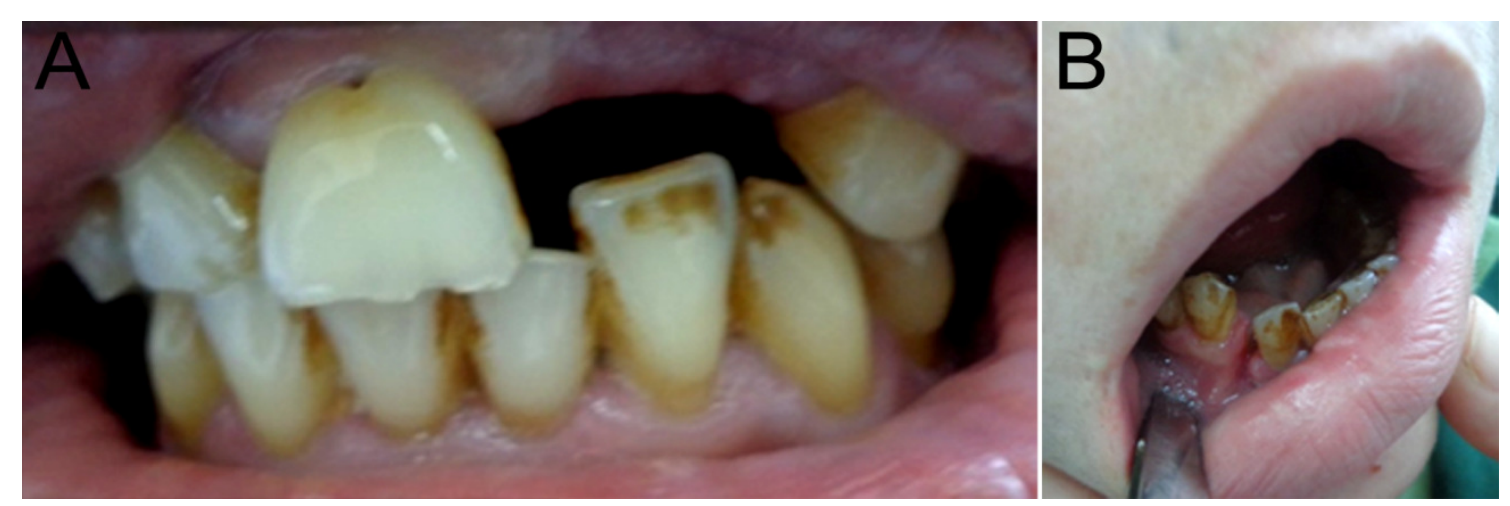

Figure 3. 30-year-old male inmate incarcerated for 5 years (A) and 29-year-old female inmate incarcerated for 4 years (B) showing as result of fighting dental loss and mandible fracture, respectively

While conflicts are frequently reported in prisons worldwide, there are habits more commonly associated with institutions of specific countries. In prisons and colonies of the Russian Federation, use of the so-called "chifir" (a drink with psychoactive effect obtained by digesting highly concentrated tea brewing) is common. There are studies confirming the antimicrobial activity of tea tannins and fluoride content to suppress saliva amylase and prevent caries (GOENKA et al, 2013), respectively. On the other hand, the high concentration of tannins in chifir could be an additional risk factor for oral mucosa hyperkeratosis and leukoplakia. Nevertheless, no clinical trials have yet been conducted to evaluate the effect of the chifir on the oral mucosa. Important is to note that leukoplakia was observed in 25 inmates $(8.2 \%)$, which represents a prevalence rate twice higher than those reported in previous studies (PARLATESCU et al, 2014). The search for lesions in the oral cavity was 
performed as an additional and qualitative phase of the present study and together with the quantitative analysis of the oral health indexes it raises the attention to preventive strategies and dental health care services among inmates of the Russian Federation. More specifically, awareness of the self health care must be promoted to achieve equity in dental treatment, especially among those with systemic diseases (NOGUEIRA, ABRAHÃO, 2009; OLIVEIRA, CARDOSO, 2004; BAJPAI, PAZARE, 2010).
KONDRATYEV, S. A. et al.

The limitations inherent to the present study include the applicability of outcomes, which are restricted to the male and female colonies in which the oral examinations were carried. Additionally, the obtained outcomes relied on clinically detectable evidences that could be improved with imaging exams. Based on that, future comparative studies are supported to enable investigations in other facilities and with radiographic equipment.

RESUMO: Investigar a prevalência de doenças bucais e os índices de higiene oral simplificado (IHOS), dentes cariados-perdidos-restaurados (CPO-D) e índice periodontal comunitário (CPI) em detentos da Federação Russa. A amostra consistiu de 175 homens e 130 mulheres encarceradas em colônias corretivas na região de Kirov, na Federação Russa. Informações relacionadas ao nível educacional, tempo de encarceramento e condição de saúde geral foram coletadas por meio de entrevistas. Adicionalmente, exames extra e intrabucais foram realizados com a finalidade de detectar possíveis doenças e lesões em dentes e tecidos moles. Análise quantitativa da saúde bucal foi conduzida por meio da investigação dos índices IHO-S, CPO-D e CPI. Estes índices foram testados estatisticamente em face de sua associação com o nível educacional e tempo de encarceramento dos detentos. Dentição completa, parcial e edentulismo foram observadas em $10.5 \%, 81.9 \%$ e $7.5 \%$ da amostra. Cárie (92.4\%), doença periodontal (55.7\% periodontite e $33.1 \%$ gengivite) e doenças pulpares $(87.9 \%)$ foram as mais prevalentes. Queilite $(64.9 \%)$, glossite $(21.9 \%)$ e estomatite nicotínica no palato $(28.8 \%)$ foram as lesões mais prevalentes em mucosa. Forte Associação positiva foi verificada entre os índices IHO-S e CPO-D e o nível educacional e tempo de encarceramento dos detentos. Quanto menor o nível educacional e maior o tempo de encarceramento, maiores foram os referidos índices $(\mathrm{p}=0.001)$. Conclusão: Estes resultados apontam para a necessidade de promoção de políticas direcionadas ao cuidado bucal em detentos encarcerados na Federação Russa.

PALAVRAS-CHAVE: Diagnóstico. Prisioneiros. Saúde bucal. Serviços de saúde comunitária.

\section{REFERENCES}

ARMANI, T. E.; CRUZ-SILVA, C. T. A. Socioeconomic and factor evaluation that lead to violence with inmates of Cascavel/PR. Ensaio Aval. Pol. Publ. Educ., Rio de Janeiro, v. 18, n. 67, p. 253-74, apr./jun. 2010.

BAJPAI, S.; PAZARE, A. R. Oral manifestations of HIV. Contemp. Clin. Dent., Mumbai, v. 1, n. 1, jan./mar. 2010.

BLIZNIUK, A.; UENO, M.; FURUKAWA, S.; KAWAGUCHI, Y. Evaluation of a Russian version of the oral health literacy instrument (OHLI). BMC Oral Health., London, v. 14, n. 1, p. 141, nov. 2014.

CARVALHO, M. L.; VALENTE, J. G.; ASSIS, S. G.; VASCONCELOS, A. G. G. Profile of prisoners in the Rio de Janeiro prison system: specificities of gender in the social exclusion process. Cienc. Saude Colet., Rio de Janeiro, v. 11, n. 2, p. 461-71, apr./jun.2006.

CÉSAR, C. P. H. A. R.; SILVA, K.; PARANHOS, L. R.; BALDRIGHI, S. E. Z. M. Quality of life of subjects with and without nose breathing difficulties. Biosci. J., Uberlândia, v. 32, n. 1, p. 272-8, Jan./Feb. 2016.

DECERLE, N.; WODA, A.; NICOLAS, E.; HENNEQUIN, M. A description of oral health in three French jails. Community Dent. Health, London, v. 29, n. 4, p. 274-8, dec. 2012. 
GOENKA, P.; SARAWGI, A.; KARUN, V.; NIGAM, A.G.; DUTTA, S.; MARWAH, N. Camellia sinesis (Tea): implications and role in preventing dental decay. Pharmacogn. Rev., Mumbai, v. 7, n. 14, p. 152-6, jul./dec. 2013.

HEIDARI E, DICKINSON C, WILSON R, FISKE J. Oral health of remand prisoners in HMP Brixton, London. Br. Dent. J., London, v. 202, n. 2, p. 1-6, jan. 2007.

LUNN, H.; MORRIS, J.; JACOB, A.; GRUMMITT, C. The oral health of a group of prisons inmates. Dent. Update., London, v. 30, n. 3, p. 135-8, apr. 2003.

NAIDOO, S.; YENGOPAL, V.; COHEN B. A baseline survey: Oral health status of prisoners -Western Cape. S. Afr. Dent. J., Johannesburg, v. 60, n. 1, p. 24-7, feb. 2005.

NOBILE, C. G. A.; FORTUNATO, L.; PAVIA, M.; CANTANZARO, I. F. A. Oral health status of male prisoners in Italy. Int. Dent. J., London, v. 57, n. 1, p. 27-35, feb. 2007.

NOGUEIRA, P. A.; ABRAHÃO, R. M. C. M. Tuberculosis infection and the length of stay of County Jails prisoners in the western sector of the city of São Paulo. Rev. Bras. Epidemiol., São Paulo, v. 12, n. 1, p. 30-8, mar. 2009.

OLIVEIRA, H. B.; CARDOSO, J. C. Tuberculosis among city jail inmates in Campinas, São Paulo, Brazil. Rev. Panam. Salud. Publica, Washington, v. 15, n. 3, p. 194-9, mar. 2004.

OSBORN, M.; BUTLER, T.; BARNARD, P. D. Oral health status of prison inmates - New South Wales, Australia. Aust. Dent. J., Sydney, v. 48, n. 1, p. 34-8, mar. 2003.

PARLATESCU, I.; GHEORGHE, C.; COCULESCU, E.; TOVARU, S. Oral leukoplakia - an update. Maedica, Bucharest, v. 9, n. 1, p. 88-93, mar. 2014.

REDDY, V.; KONDAREDDY, C. V.; SIDDANNA, S.; MANJUNATH, M. A survey on oral health status and treatment needs of life-imprisoned inmates in central jails of Karnataka, India. Int. Dent. J., London, v. 62, n. 1, p. 27-32, feb. 2012.

SILVA, F. F.; BENDICTO, E. N.; PARANHOS, L. R. Professional practice of dentist in front of the national policy of morbidity reduction by accidents and violence. Biosci. J., Uberlândia, v. 29, n. 4, p. 1064-1070, Jul./Aug. 2013.

WALSH, T.; TICKLE, M.; MILSOM, K.; BUCHANAN, K.; ZOITOPOULOS, L. An investigation of the nature of research into dental health in prisons: a systematic review. Br. Dent. J., London, v. 204, n. 12, p. 6839, jun. 2008. 